\title{
Current Status Of Municipal Solid Waste Management In Ukraine
}

\author{
Liydmyla Haponych $^{1}$, Iryna Golenko ${ }^{2}$, Alexander Topal ${ }^{3}$ \\ 1. Coal Energy Technology Institute, The National Academy of Sciences of Ukraine, UKRAINE, \\ Kyiv, 19, Andriyvska str., E-mail: haponych@ukr. net \\ 2. Coal Energy Technology Institute, The National Academy of Sciences of Ukraine, UKRAINE, Kyiv, \\ 19, Andriyvska str., E-mail: ilv.golenko@gmail.com \\ 3. Coal Energy Technology Institute, The National Academy of Sciences of Ukraine, UKRAINE, Kyiv, \\ 19, Andriyvska str., E-mail: dr.topal@ gmail.com

\begin{abstract}
The status of existing legislation on waste management in $E U$, Ukraine and worldwide has been considered. Special features of EU Directives on waste management are considered. Different technologies of waste utilization including grate firing, gasification and pyrolysis and plants performance where they are used are briefly analyzed. Special attention is drawn to current situation in Ukraine related to MSW.
\end{abstract}

Keywords - Waste Management, Municipal Solid Waste (MSW), Refuse Derived Fuel (RDF), incineration, Best Available Techniques, Waste-to-Energy Plant.

\section{Introduction}

On 16 September 2014 Verhovna Rada (Supreme Council of Ukraine) and European Parliament simultaneously approved Association Agreement between the European Union and the European Atomic Energy Community and their member states, of the one part, and Ukraine, of the other part. This EU-Ukraine Association Agreement completely entered into force on 1 September 2017 becoming a part of national legislation. As a result it is assumed stepwise approaching the Ukrainian legislation to EU one in the field of energy efficiency, renewable energy sources, climate change, tax on emissions and wastes as well as waste management. According to Association Agreement the obligations of Ukraine related to climate change are defined. In the Agreement the protection of the environment is considered to be high priority one as well as harmonization of national legislation with policy and laws of $\mathrm{EU}$ in the field of the environment protection in 8 sectors: 1) environmental governance and integration of environment into other policy areas; 2) air quality; 3) waste and resource management; 4) water quality and water resource management, including marine environment; 5) nature protection; 6) industrial pollution and industrial hazards; 7) climate change and protection of the ozone layer; 8) genetically modified organisms.

Policy regarding the waste management in EU is defined by eight Directives from which three ones are included in the list of Agreement: 1) Framework Directive 2008/98/EC of the European Parliament and of the Council of 19 November 2008 On waste and repealing certain Directives; 2) Council Directive 1999/31/EC of 26 April 1999 On the landfill of waste; 3) Directive 2006/21/EC of the European Parliament and of the Council of 15 March 2006 On the management of waste from extractive industries. The implementation of the above Directives needs significant changes and additions to national legislation relevant to waste management. The time period of introduction of Directives is to be from 2 to 5 years from 2019 till 2022.

Framework Directive 2008/98/EC regarding waste sets legislative base and main rules on waste management which allow both to decrease the amount of waste storage and to provide resource saving due to re-use and treatment of secondary feedstock. Directive sets implementation of hierarchy of priorities on waste regulating including: prevention and minimization of its formation (due to economic stimulation - incentive, special tax, educational campaign etc); preparation for re-use; treatment, including composting; utilization incl. energy re-use; ecologically safe storage at disposal dump. To achieve high quality of waste treatment, Directive obliges to introduce separate gathering of waste at 
least paper, metal, plastics and glass. Waste utilization is the use of waste as secondary material or energy resources. Definition of "re-use" also covers production of alternative fuel from waste including MSW. Directive sets up unified waste classification in EU member states including hazardous, regulating the order of how to classify wastes as hazardous and control them. Such classification is set up by the Decision of Commission 2000/532/EC of 3 April 2000. Directive obliges introduction of principle «contaminators pay» by means of extended responsibility for producer - financial and organizational mechanism of provision to closed loop of treatment. This means that producer takes responsibility for treatment and utilization of its goods after consumption. Directive also obliges to follow obligations related approval certain procedures related to producer. Necessary condition needed to obtain approve on combustion or co-firing of wastes aimed at energy utilization is the necessity to re-use energy as energy efficient as possible.

Basic EU document in the field of protection the environment that regulates emissions from industrial plants is Directive 2010/75/EC of 24 November 2010 p. - (the Industrial Emissions Directive or IED). Directive IED aims to achieve high degree of protection of the environment by means of decrease in harmful industrial emissions by implementation of Best Available Techniques or BAT. Term "best" means most effective from the standpoint of achievement of high general level of environment protection. Directive has criteria to define BAT (Annex III). Directive IED also covers waste management - waste combustion, storage at landfill. According to Directive 2010/75/EU, operation of waste incineration (and co-incineration) plant can be done only in case of availability of integrated permit. The conditions of the permit are formulated on the basis of Reference Document On The Best Available Techniques (BREFs) For Waste Incineration (WI BREF) 2006. In 2019 it is planned to announce new WI BREF.

On 28 March 2019 President P. Poroshenko signed Law «On Basic concept (strategy) of ecological policy of Ukraine by the period of 2030 year». This law makes provision the decrease in the amount of waste storage at landfill dumps in 2030 till 35\%. Important phase of implementation of conditions of EU directives relevant waste management is adoption of National strategy on waste management in Ukraine till the year of 2030 (Regulation of SCU of Ukraine № 820-p of 8 November 2017). The strategy will formulate general directions and define state policy in the field of waste management. The objective of the Strategy is to clean the environment and decrease waste that goes to landfill. Priority direction is to convert waste on resources and decrease amount of waste. Strategy covers all territory of Ukraine and considers such waste source as MSW, construction waste, hazardous waste, another industrial waste (except for hazardous), agricultural waste, electrical and electronic waste, charged-out batteries and accumulators. Tools to realize the Strategy is National plan to manage wastes approved by SCU of 20 February 2019. National plan defines tasks and applied measures which implementing allows for Ukraine to implement a new model to manage waste as that being in force in EU. National plan to manage waste, in particular, foresees formulation of public policy in the field of waste management, creation of effective system of waste gathering and its disposal etc. Framework draft-law "On waste management" is at the final stage of approval. Beginning from 01.01.2018 the correction to Law of Ukraine «On waste» (art. 32), was put into force forbidding storage of un-treated MSW at landfills.

\section{Main material}

MSW is classified as waste that is gathered by municipality or another municipal authorities. In most cases MSW includes: household waste, waste formed in gardens, yards, parks, waste from retailers and public organizations.

The amount of MSW in Ukraine during the last years is considered to be 10-12 mln t (50-60 mln

$\mathrm{m}^{3}$ ) (Table. 1, source: Ministry of regional development, construction and municipal industry of 
Ukraine, Public Bureau of statistics of Ukraine). In 2000 in Ukraine it was produced about $180 \mathrm{~kg}$ of MSW per person, but in 2017-2018 it exceeds $250 \mathrm{~kg}$. Only $77-78 \%$ of population in Ukraine can obtain service on MSW disposal. Beside this, in 2017 p. it was formed 11,8 ths t of MSW of 1-3 hazardous class and only 1.9 ths of them was disposed in special landfills.

Table 1

MSW management in Ukraine in 2014-2018

\begin{tabular}{|c|c|c|c|c|c|c|c|c|c|}
\hline \multirow[t]{2}{*}{ Year } & \multicolumn{2}{|c|}{ Amount of gathering } & \multirow{2}{*}{$\begin{array}{c}\begin{array}{c}\text { Points of } \\
\text { secondary } \\
\text { feedstock }\end{array} \\
\text { ths t }\end{array}$} & \multirow{2}{*}{$\begin{array}{c}\text { Waste } \\
\text { management } \\
\text { plants }\end{array}$} & \multirow{2}{*}{$\begin{array}{c}\begin{array}{c}\text { Site for } \\
\text { compo-sting }\end{array} \\
\text { ths } \mathrm{t}\end{array}$} & \multicolumn{2}{|c|}{$\begin{array}{c}\text { Incineration } \\
\text { plants }\end{array}$} & \multicolumn{2}{|c|}{ Landfills } \\
\hline & ths $\mathrm{t}$ & $\mathrm{kg} /$ person & & & & ths $t$ & $\%$ & ths $t$ & $\%$ \\
\hline 2014 & 10748.0 & 250.0 & 142.3 & 73.0 & 0 & 149.5 & 1.4 & 10383.2 & 96.6 \\
\hline 2015 & 11491.8 & 268.5 & 132.5 & 128.3 & 2.8 & 254.3 & 2.2 & 10973.9 & 96.6 \\
\hline 2016 & 11562.6 & 271.0 & 126.6 & 143.8 & 1.6 & 256.7 & 2.2 & 11033.9 & 95.4 \\
\hline 2017 & 11271.2 & 265.3 & 146.2 & 259.9 & 0.97 & 246.7 & 2.2 & 10615.1 & 94.2 \\
\hline 2018 & 10679.3 & 253.7 & 146.5 & 260.1 & 1.6 & 208.1 & 1.9 & 10063.0 & 94.2 \\
\hline
\end{tabular}

In 2018 in Ukraine it was treated and utilized just 5.8\% of MSW, incl. 1.9\% was incinerated (burntout), 3.9\% went to gathering sites, points of secondary feedstock and incineration plants. $26 \mathrm{MSW}$ sorting lines, 1 incineration plant (Kyiv, factory Energia) and 3 waste-fired facilities were in operation. In 2017 separate gathering of MSW was introduced at 822 small towns, in 2018 - at 1181. There exists in Ukraine 460 cities, 500 regions, 885 small towns and 28388 villages. Among all amount of gathered MSW - $94 \%$ is a mixed waste.

Almost $95 \%$ of gathered MSW (10 - $11 \mathrm{mln} \mathrm{t})$ in Ukraine is disposed on landfills. As of the end of 2018 Ukraine has 6107 landfills, incl. 256 is overloaded ones, 984 - don't meet safety conditions. Total area of landfills and dumps is about 9172.4 ha, area of landfills that don't meet safety -1753.1 ha. Based on National strategy to manage waste in Ukraine till 2030, more than $99 \%$ of landfills in operation don't meet EU conditions of Directive 1999/31/CC «On waste disposal». Beside this, more than 30 ths. non-permitted landfills are created annually. Based on MERT info in 2017, 30184 such landfills were formed occupying area more than 896,07 ha. Almost about $19.1 \mathrm{mln} \mathrm{m}^{3}(3626.4 \mathrm{ths} \mathrm{t})$ of MSW was disposed in a non-permitted manner in 2017.

Besides this, one of the problem of MSW landfills disposal is biochemical decomposition of waste that results in dump gas formation that is consisted of greenhouse gas $-\mathrm{CH}_{4}(55-60 \%)$ and $\mathrm{CO}_{2}$ [1] . Accumulation of methane in a body of landfill may lead to MSW self-ignition. Uncontrolled combustion is accompanied with formation of toxic compounds such as dioxins. According to the Intergovernmental Panel on Climate Change (IPCC. ch), landfill emissions contribute to $18 \%$ of the total methane emissions to the atmosphere, giving from 9 to 70 megatons annually. As the above mentioned, Law of Ukraine «On waste» forbids storage of untreated MSW. National strategy foresees to achieve by 2023 such targets: treatment of $15 \%$ of MSW, separate gathering of MSW from $23 \%$ of population, and in $2030-50 \% \mathrm{MSW}$ and $48 \%$ population correspondingly.

One of measures that allows both eliminate influence of MSW greenhouse gas decomposition in air, ground water and the environment contamination, biological stabilization of waste and significantly reduce the volume of waste (by $90 \%$ ) and weight (by $75 \%$ ) is incineration. MSW is the burning of waste in a controlled process within a specific plant that has been built for this reason. The primary objective of incineration is to reduce MSW volume and mass and also make it chemically inert in a combustion process avoiding additional fuel use (autothermic combustion). In addition it also gives recovery of energy, minerals and metals from the waste stream. Term «Waste-to-Energy» includes 
various types of technologies for treatment of waste to obtain energy as heat, electricity or as alternative fuel, thus, heat treatment of waste at waste-fired plants, production and combustion of RDF (Refuse Derived Fuel). Set of technologies «WtoE» is one of promising way to save organic fuel and decrease emissions of greenhouse gases. It is also an economically and ecologically sound method to ensure a renewable source for energy while diverting waste from landfills. Waste to energy is one of the robust energy options to reduce $\mathrm{CO}_{2}$ emissions and replace fossil fuels. Approximately 2/3 of household waste is categorized as biomass. Therefore, we can recover $2 / 3$ as $\mathrm{CO}_{2}$-neutral energy and reduce our dependence on fossil fuels.

Incineration follows separate gathering and/or sorting of MSW. Such components as paper, glass, plastics and metal go to recycling. Organic compounds - plants and rest of meals - are fed to composting or landfill. The rest wastes (almost one third of MSW) - is source for future fuel. It was pressed in briquettes or granules. Obtaining the Refuse Derived Fuel (RDF) is the process of removing the recyclable and noncombustible from the MSW and producing a combustible material, by shredding or pelletizing the remaining waste. Several types of RDFs can be made, such as coarse, fluffy, powdered or densified, depending on the composition of the refuse, and the technology used. The benefits of such approach are as follows: wastes becomes useful goods that can be accumulated, stored, transported.

Waste-to-Energy was traditionally widely used in countries having deficit of free area for waste disposal. Despite this, even in Australia in the Kwinana Industrial Area around $40 \mathrm{~km}$ south of Perth in 2018 it was started construction of first Waste-to-Energy plant with $36 \mathrm{MWe}$ and annual capacity of 400 ths $t$ of waste. Now in the world more than 2600 WtoE plants are in operation incl. 500 is in Europe, 100 plants in North America and 1600 in Asia. In Table 2 the number and productivity of WtoE plants working in EU are presented (Source: EUROSTAT 2019, Confederation of European Waste-to-Energy Plants (CEWEP). It is also given information on Norway and Ukraine. In EU in 2017 the part of MSW, that was burnt-out while energy re-involving, achieved $28.1 \%$ of total MSW amount, in Ukraine - just 2,2\%. Now, according to CEWEP, W(MSW)toE plants in EU can provide with electricity about 19 millions of people and with heat about 16 millions people. In 2016 these plants produced $40 \mathrm{mln} \mathrm{kW} \cdot \mathrm{h}$ of electricity and $93 \mathrm{mln} \mathrm{kW} \cdot \mathrm{h}$ of heat.

In USA, in 2016, 71 power plants generated about 14 billion kWh of electricity from burning about 30 million tons of combustible MSW, 12,8\% of total amount of MSW in USA (as to U.S. Environmental Protection Agency). In USA more than 119 WTE plants are now in operation including those with direct combustion (mass burn and RDF): 100 plants - mass burn (burns/combusts everything), 19 - RDF combustion.

In Japan $45 \mathrm{mln} \mathrm{t}$ of MSW is annually formed. Japan is a world leader in implementing incineration technologies - more than $75 \%$ of MSW is burnt and among them more than $30 \%$ with electricity producing. Japan has about 1500 incineration plant, from which in Tokyo from 1983 to 2017 p. was put into operation 21 incineration plants (Table 3 as to Clean Authority of Tokyo).

Despite incineration is by far the most widely applied, there are three main types of thermal waste treatment such as: incineration - full oxidative combustion (the most common process); gasification partial oxidation; pyrolysis - thermal degradation of organic material in the absence of oxygen.

Combustion can be applied as mass burn (burns/combusts everything without pre-treatment) and RDF-burn, gasification as conventional gasification and plasma arc gasification. In accordance to BAT, pyrolysis and gasification are rarely applied for heat treatment of MSW and RDF. Grate (or Stokerfiring) incinerators are widely used for the incineration of mixed municipal wastes. In Europe approximately $90 \%$ of installations treating MSW use grates. Fluidized bed incinerators are widely applied to the incineration of finely divided wastes such as RDF. 
Table 2

The amount of MSW, share of its combustion at incineration plants, EU, Ukraine and Norway plants performance in 2017

\begin{tabular}{|c|c|c|c|c|c|}
\hline \multirow{3}{*}{ Country } & \multicolumn{3}{|c|}{ MSW amount } & \multicolumn{2}{|c|}{ Waste-to-Energy plants } \\
\hline & \multirow{2}{*}{$\begin{array}{c}\text { Total, } \\
\text { ths t }\end{array}$} & \multicolumn{2}{|c|}{ Waste-to-Energy } & \multirow{2}{*}{$\begin{array}{c}\text { Number } \\
\text { Units }\end{array}$} & \multirow{2}{*}{$\begin{array}{l}\text { Capacity } \\
\text { ths t/yeal }\end{array}$} \\
\hline & & ths $\mathrm{t}$ & $\% *$ & & \\
\hline European Union - 28 countries & 248655 & 69953 & 28.1 & 487 & 91660 \\
\hline Belgium & 4659 & 2002 & 43.0 & 18 & 3410 \\
\hline Bulgaria & 3080 & 103 & 3.3 & - & - \\
\hline Czechia & 3643 & 634 & 17.4 & 4 & 700 \\
\hline Denmark & 4503 & 2380 & 52.9 & 26 & 3470 \\
\hline Germany & 52342 & 16185 & 30.9 & 121 & 26000 \\
\hline Estonia & 514 & 217 & 42.2 & 1 & 240 \\
\hline Ireland (in 2016) & 2763 & 811 & 29.4 & 1 & 230 \\
\hline Greece & 5415 & 58 & 1.1 & - & - \\
\hline Spain & 21530 & 2780 & 12.9 & 12 & 2880 \\
\hline France & 34393 & 12220 & 35.5 & 126 & 14400 \\
\hline Croatia & 1716 & 1 & 0.1 & - & - \\
\hline Italy & 29583 & 5634 & 19.0 & 41 & 6210 \\
\hline Cyprus & 547 & 2 & 0.4 & - & - \\
\hline Latvia & 851 & 21 & 2.5 & - & - \\
\hline Lithuania & 1286 & 236 & 18.4 & 1 & 260 \\
\hline Luxembourg & 362 & 161 & 44.5 & 1 & 160 \\
\hline Hungary & 3768 & 608 & 16.1 & 1 & 350 \\
\hline Malta & 283 & 0 & 0.0 & - & - \\
\hline Netherlands & 8787 & 3901 & 44.4 & 12 & 7800 \\
\hline Austria & 5018 & 1944 & 38.7 & 11 & 2500 \\
\hline Poland (in 2016) & 11969 & 2922 & 24.4 & 5 & 500 \\
\hline Portugal & 5012 & 974 & 19.4 & 4 & 1200 \\
\hline Romania & 5325 & 227 & 4.3 & - & - \\
\hline Slovenia & 974 & 111 & 11.4 & 12 & 2900 \\
\hline Slovakia & 2058 & 197 & 9.6 & 2 & 290 \\
\hline Finland & 2812 & 1646 & 58.5 & 8 & 1470 \\
\hline Sweden & 4551 & 2400 & 52.7 & 34 & 5990 \\
\hline United Kingdom & 30911 & 11578 & 37.5 & 46 & 10700 \\
\hline Norway & 3949 & 2088 & 52.9 & 17 & 1610 \\
\hline Ukraine & 11271 & 247 & 2.2 & 1 & 247 \\
\hline
\end{tabular}

The incinerators required by different waste-energy combustion ways (mass burn, RDF, incineration, gasification, pyrolysis) are markedly different, and so are their costs and environmental impacts. Mass burn is typically a low efficiency approach. While it eliminates large amounts of refuse, little energy is recovered. Typically, not sorted MSW has an average heating value of 8 to $12 \mathrm{MJ} / \mathrm{kg}$, in comparison with $19 \mathrm{MJ} / \mathrm{kg}$ for dry wood, $15 \mathrm{MJ} / \mathrm{kg}$ for lignite or $22 \mathrm{MJ} / \mathrm{kg}$ for steam coal.

Waste-to-Energy plants are characterized by high CAPEX. According to Renewable Energy World company ranges for CAPEX for each of the thermal technologies assume a $15 \mathrm{MW}$ output for a: direct 
combustion (Mass Burn and RDF) varies from $\$ 7,000$ to $\$ 10,000$ per $\mathrm{kW}$; pyrolysis ranges from $\$ 8,000$ to $\$ 11,500$ per $\mathrm{kW}$; conventional gasification varies from $\$ 7,500$ to $\$ 11,000$ per $\mathrm{kW}$; plasma arc gasification ranges from $\$ 8,000$ to $\$ 11,500$ per $\mathrm{kW}$. Costs vary from technology to technology due to each having unique design characteristics, variations in equipment costs, site specific waste characteristics and site space requirements. There are significant other factors that can negatively affect the costs of construction - location of plant in a city, limited construction, high architectural requirements etc. Now in Ukraine waste disposal at landfills remains the cheapest while high dirty way доf MSW management. Tax for MSW disposal in Ukraine is 4,5 UAH/t or 0,15 euro/t, but in Holland 107, Belgium - 82, Finland - 70, Denmark - 65, Great Britain - 64, Sweden - 49, Poland - 27, Austria 26, France - 20 euro/t (as to State Agency on Energy Efficiency and Energy Saving of Ukraine). The future of energy utilization of MSW in Ukraine will become feasible only when the waste disposal cost be higher its treatment/utilization.

Table 3

Tokyo's Incineration Plants

\begin{tabular}{|c|c|c|c|c|}
\hline Plant & Company producer, type* & $\begin{array}{c}\text { Capacity, } \\
\text { tons day } \\
\text { furnaces }\end{array}$ & $\begin{array}{c}\text { Maximum } \\
\text { heating value, } \\
\mathrm{kJ} / \mathrm{kg}\end{array}$ & $\begin{array}{c}\text { Power } \\
\text { generation } \\
\text { capacity, } \mathrm{kW}\end{array}$ \\
\hline Hikarigaoka & $\begin{array}{c}\text { A, Mitsubishi Heavy Industries } \\
\text { Environmental \& Chemical Engineering } \\
\text { Co., Ltd. (MHIEC) }\end{array}$ & $150 \times 2=300$ & 11,3 & 4,0 \\
\hline Meguro & A, Nippon Kokan Corp & $300 \times 2=600$ & 11,7 & 11,0 \\
\hline Ariake & A, MHIEC, reconstruction planned & $200 \times 2=400$ & 14,2 & 5,6 \\
\hline Chitose & A, Kawasaki Sun & $600 \times 1=600$ & 12,1 & 10,0 \\
\hline Edogawa & A, Nippon Kokan Corp & $300 \times 2=600$ & 12,1 & 12,3 \\
\hline Sumida & A, Hitachi Zosen & $600 \times 1=600$ & 13,0 & 13,0 \\
\hline Kita & A, MHIEC & $600 \times 1=600$ & 12,1 & 11,5 \\
\hline Shin-Koto & A, TAKUMA-type HN & $600 \times 3=1800$ & 13,4 & 50,0 \\
\hline Minato & A, MHIEC & $300 \times 3=900$ & 13,4 & 22,0 \\
\hline Toshima & B, Ishikawajima-Harima Heavy Industries & $200 \times 2=400$ & 13,4 & 7,8 \\
\hline Shibuya & B, Ebara Corporation Rotational flow & $200 \times 1=200$ & 13,4 & 4,2 \\
\hline Chuo & A, Hitachi Zosen & $300 \times 2=600$ & 13,4 & 15,0 \\
\hline Itabashi & A, Sumitomo W+E-type & $300 \times 2=600$ & 12,1 & 13,2 \\
\hline Tamagawa & A, Ishikawajima-Harima Heavy Industries & $150 \times 2=300$ & 12,1 & 6,4 \\
\hline Adachi & A, Ebara HPCC & $350 \times 2=700$ & 12,1 & 16,2 \\
\hline Shinagawa & A, Hitachi Zosen & $300 \times 2=600$ & 12,1 & 15,0 \\
\hline Katsushika & A, Takuma SN & $250 \times 2=500$ & 12,1 & 13,5 \\
\hline Setagaya & C, Kawasaki Fluidized bed type & $150 \times 2=300$ & 12,1 & 6,75 \\
\hline Ota & A, TAKUMA-type SNF type & $300 \times 2=600$ & 14,8 & 22,8 \\
\hline Nerima & A, JFE & $250 \times 2=500$ & 14,3 & 18,7 \\
\hline Suginami & A, Hitachi Zosen & $300 \times 2=600$ & 14,3 & 24,2 \\
\hline
\end{tabular}

*Incinerator types: A - Stoker furnace (Full continuance combustor), B - Fluidized bed furnace (Full continuance combustor), $\mathrm{C}$ - Gasification melting furnace (All continuous operation)

In Ukraine the only one incineration plant is in operation Energia (Kyiv) having maximum annual capacity of 300 ths $t$ of MSW. MSW is burnt at the temperature of $900-1000{ }^{\circ} \mathrm{C}$. Plant can produce 227 ths Gcal of heat and up to $50,7 \mathrm{mln} \mathrm{kW} \cdot \mathrm{h}$ electricity per year. According to National strategy to manage waste in Ukraine it is planned to increase the level of thermal treatment of MSW up to $10 \%$ of total 
amount by means of construction of 19 heat treatment utilization plants for MSW. Composition of MSW is one of important parameters affecting the technology selection. According to National strategy average morphological composition of MSW in Ukraine is as follows: organic waste - 30\%, cellulosecontaining material (paper, cardboard, newspapers, wrapping etc.) - 17\%; metals - 3\%; polymers $11 \%$; glass, ceramics $-6 \%$; hazardous waste $-1 \%$, others $-32 \%$. The share of waste having organic compound is 70-78\%. Morfological composition of MSW significantly changes over the year seasons: in summer and autumn - the share of organic waste increases while in winter - non-organic waste dominates.

As to Kyiv, based on State-owned R\&D and Design \& Technological Institute of Municipal Economy, in 2011 average morphological composition of MSW was as follows: paper, cardboard $13.24 \%$, food and garden waste $-39.26 \%$, plastics, PETF bottles and boxes, polymer film, TetraPak package $-10.23 \%$, black and colored metals $-1.11 \%$, tree $-1.35 \%$, textile, skin $-2.79 \%$, glass $13.01 \%$, hazardous waste $-0.01 \%$, not-sorted combustible rest $-14.68 \%$, not-sorted non-combustible mineral waste $-4,31 \%$. Average ultimate and proximate analyses of Kyiv MSW: $\mathrm{C}^{\mathrm{r}}=16.54 \%, \mathrm{H}^{\mathrm{r}}=$ $2.36 \%, \mathrm{O}^{\mathrm{r}}=13.69 \%, \mathrm{~N}^{\mathrm{r}}=0.54 \%, \mathrm{~S}^{\mathrm{r}}=0.13 \%, \mathrm{~A}^{\mathrm{r}}=18,2 \%, \mathrm{~W}^{\mathrm{r}}=39.03 \%$, heating value $-6,2-6,3 \mathrm{~kJ} / \mathrm{kg}$. After selection of secondary feedstock at sorting line, water content increases up to $48.3 \%$. In this case heating value of sorted MSW decreases till 5,4-5,5 kJ/kg and becomes too low for direct combustion. After selection of secondary feedstock and separation from waste mineral non-combustibles and organic components, capable of biological decay, water content of wastes decreases up to $25 \%$, and heating value increases to $10,4-10,5 \mathrm{~kJ} / \mathrm{kg}$. Such wastes are applicable for RDF production.

Limiting emissions in flue gases from energy plants including incineration ones should comply with Directive 2010/875/EC on industrial emissions (Table 4). It is seen that requirements of Directives 2010/75/EU significantly affect the thermal technology selection for MSW/RDF utilization and proper flue treatment.

Table 4

Emissions requirements of Directive 2010/75/EC on industrial emissions

\begin{tabular}{|l|c|c|c|c|c|c|c|c|c|c|c|}
\hline Substances, $\mathrm{mg} / \mathrm{Nm}^{3}$ & Dust & $\mathrm{TOC}$ & $\mathrm{HCl}$ & $\mathrm{HF}$ & $\mathrm{SO}_{2}$ & $\mathrm{NO}_{\mathrm{x}}$ & $\mathrm{CO}$ & $\mathrm{Cd}+\mathrm{Tl}$ & $\mathrm{Hg}$ & $\begin{array}{c}\text { Heavy } \\
\text { Metals }\end{array}$ & $\begin{array}{c}\text { Dioxins and } \\
\text { Furans }\end{array}$ \\
\hline Waste Incineration & 10 & 10 & 10 & 1 & 50 & 200 & 50 & 0.05 & 0.05 & 0.5 & 0.1 \\
\hline Co-incin. in Cement Kiln & 30 & 10 & 10 & 1 & 50 & 500 & - & 0.05 & 0.05 & 0.05 & 0.13 \\
\hline
\end{tabular}

\section{Conclusion}

Based on the above mentioned the following recommendations and conclusions can be summarized as follows. The problem of optimal waste management is actual all over the world. The trends and obligations to manage waste in proper way are available worldwide becoming a part of leading countries national legislation. The main trend in leading countries assume that MSW should be separately gathering, further proper sorted, valuable components should be recycled and secondary refused fuel should also be derived and then utilized as much as possible. Waste disposal on landfills must be as little as possible while the principle of circulating economy should be deeply implemented. Great amount of energy can be derived from MSW in a form of RDF that can substitute limited fossil resources while using secondary fuel for electricity and heat production in environmentally sound manner. Ukraine faces a lot of issues concerning the proper waste management implementation both in legislation and technology introduction accounting for EU requirements on industrial emissions.

\section{References}

[1] I. L. Trofimov, "Ocinka vplyvu vidxodiv pobutovogo poxodzhennya na ekologichnyj stan Ukrayiny", Vostochno-Evropeyskiy zhurnal peredovyih tehnologiy, vol. 2, no. 10, pp. 25-29, 2014 year. 